\title{
REPUBLICANISMO Y CRISTIANISMO
}

\author{
Demetrio Velasco
}

Cuando escribo estas páginas, un nutrido y escogido grupo de intelectuales y políticos debaten en Madrid, en un seminario celebrado con ocasión del XXV aniversario del diario El País, sobre la Democracia del milenio. El pesimismo expresado casi de forma generalizada ante el futuro de la democracia se basa en la constatación de graves peligros (como la forma en que se está realizando la globalización, los nacionalismos excluyentes, la corrupción, el control oligárquico de los medios de comunicación social) que amenazan con su destrucción. Un artículo de U. Eco, titulado «Las elecciones italianas, un referéndum moral» ${ }^{1}$, describe el penoso panorama de una sociedad aquejada de la denominada «anomalía italiana», que explicaría la temida victoria de Berlusconi. La mayoría de los italianos que apoyan a Berlusconi se dividen en dos grandes grupos: el de quienes él llama «electorado motivado», formado por quienes le apoyan por convicción efectiva, pero de dudoso talante democrático (neofascistas, oligarquías, nacionalistas xenófobos y excluyentes), y el del «electorado encantado», formado por ciudadanos manipulados por los medios de comunicación, sobre todo por la televisión, que de forma alarmante controla el mismo Berlusconi. Estos ignoran el alcance de las cuestiones constitucionales o fiscales. Es «un electorado totalmente insensible a toda crítica, a toda acusación y está fuera de toda preocupación por el sistema de hecho. Es un electorado producido por nuestra sociedad, con años y años de atención a los valores del éxito y de la riqueza fácil...». Para acabar de describir este desolador paisaje, se refiere Eco al «electorado desmotivado» de la izquierda, que es el que tiene más responsabilidad, ya que, según él, las

1 U. Ecco. «Las elecciones italianas, un referéndum moral». El País. 11/V/2001; son también las vísperas de las elecciones en el País Vasco, del que se pueden decir casi las mismas cosas. 
elecciones mencionadas «son un referéndum moral al que nadie tiene derecho a sustraerse». Obviamente, si lo que Eco dice de la sociedad italiana es, como yo lo creo, extrapolable a bastantes de las sociedades democráticas de nuestro entorno, estamos confrontados ante un problema moral de gran envergadura y no sólo de mera coyuntura política.

Las páginas que siguen presentan algunos de los intentos de la reflexión política actual de buscar terapias plausibles a las patologías democráticas mencionadas. En efecto, el republicanismo, como otros «ismos» surgidos ante la alarma que nos produce la pérdida de lo que académicamente se denomina «capital social» ${ }^{2}$, es una búsqueda de soluciones a una situación de crisis moral, de astenia colectiva, de pérdida de virtudes civiles, de corrupción institucionalizada, en nuestras sociedades. R. Putnam, autor que ha analizado con solvencia y desde una perspectiva tocquevilliana la relación intrínseca que existe entre civilidad y vigencia de las instituciones democráticas, está denunciando con un tono provocador el agotamiento progresivo que de este capital social se está dando en la sociedad norteamericana. En las últimas décadas los estadounidenses leen menos periódicos, son menos participativos en asociaciones y en actividades públicas, en general, y son cada vez más individualistas (llegan a jugar solos a los bolos...) $)^{3}$. Las redes de solidaridad y cooperación y la confianza están desapareciendo de forma alarmante.

También desde el cristianismo, al menos desde algunas de sus versiones más genuinas, se intenta aportar la virtualidad liberadora y humanizadora de las relaciones sociales propia del cristianismo, moralizando así una vida pública que tanta necesidad tiene de recursos

2 El estudio del capital social se ha convertido en un objetivo relevante de las ciencias sociales, ya que se ha empleado como clave explicativa de diferentes fenómenos, como la creación del capital humano, la efectividad de las instituciones democráticas, el desarrollo económico, o, en general, como un recurso para la solución de los problemas de acción colectiva. Se pueden distinguir dos grandes líneas de definición y de análisis del capital social: la estructural (Bourdieu y Coleman), que lo entiende como la cantidad de recursos de que el individuo puede disponer cuando participa de las redes sociales; y la cultural (Newton, Stolle), que lo entiende como un fenómeno subjetivo y se centra en las actitudes y valores de los individuos. Putnam asume aspectos de las dos líneas, aunque quizá prime más la cultural. Véase el número monográfico de la revista Zona Abierta dedicado al tema. (N. 94/95. 2001).

3 Véase la referencia al autor en H. Béjar, El corazón de la república. Avatares de la virtud política. Paidós. Barcelona. 2000, pp. 156-158. Véase asimismo A. de Francisco. «Republicanismo y Modernidad» en Claves de Razón Práctica. N. 95. 2000, p. 42, quien cita, junto a Putnan; a Bellah o Sandel, como ejemplo de «la preocupación mostrada por el pensamiento moral y político norteamericano ante el vaciamiento cívico de la sociedad contemporánea». 
morales para su regeneración. Veremos hasta qué punto republicanismo y cristianismo son compatibles en la realización de este empeño democratizador de nuestras sociedades, saliendo así al paso de algunas posiciones republicanas que los consideran incompatibles.

\section{Mirando a nuestra historia reciente}

Después del fracaso del llamado «socialismo real», y ante la amenaza de un proceso de globalización economicista que, a pesar de la legitimación neoliberal, deja patente cada vez con mayor claridad el abismo que se abre ante nuestros pies si no somos capaces de echar mano del freno de emergencia y cambiar radicalmente de rumbo, hemos tomado conciencia de que hay que buscar otras fórmulas menos inadecuadas que la de la democracia liberal actualmente hegemónica.

Hasta ahora, cuando hemos configurado modelos de sociedad democrática para responder a nuestros retos, lo hemos hecho bebiendo de las dos tradiciones que han alimentado nuestra época moderna: la tradición nacida de la revolución liberal americana y la tradición nacida de la revolución francesa. Teóricamente, a pesar de las grandes diferencias entre ambas tradiciones, en lo que respecta a la relación entre individuo — sociedad civil - Estado y en la concepción del bien común, comparten una misma preocupación: la de lograr que los individuos trasciendan sus pasiones e intereses egoístas y se comporten con la moralidad que exige la vida en común con los demás, la vida democrática. Como dicen Offe y Preuss, «podría incluso mantenerse que los dispositivos institucionales que favorecen la educación de las preferencias políticas es el único problema que las dos tradiciones democráticas mantienen en común. ¿Cómo puede transformarse la "materia prima" de la voluntad popular, con toda su ceguera, egoísmo y miopía, en una serie de productos razonables y no susceptibles de ser deplorados con posterioridad?» ${ }^{4}$. Se trata, por tanto, de lograr que los individuos actúen consciente y responsablemente y, para ello, ambas tradiciones nos siguen planteando un dilema fundamental: «El dilema es el siguiente: ¿deberían las instituciones o constituciones democráticas construirse en torno a la voluntad "empírica" del pueblo o más bien en torno a su voluntad "razonable"? ¿Debieran las reglas y procedimientos constitucionales ser considerados primeramente como un

4 Offe, C. y Preuss, U. «Instituciones democráticas y recursos morales», en Isegoría. N. 2. 1990 , pp. $45-74$. 
mecanismo de controles, equilibrios, dispositivos autovinculantes o autopaternalistas que imponen sin distinción restricciones sobre las elites gobernantes y los ciudadanos, o debieran ser más bien vistas como mecanismos de capacitación diseñados para alterar y «desnaturalizar» la voluntad empírica del pueblo, aproximándola así a una cierta noción de voluntad razonable?... ¿Es el pueblo empírico como multitud de individuos el que constituye la base y el punto de referencia de una política democrática o lo es el pueblo que debe alcanzarse en última instancia como cuerpo colectivo con una historia y un destino comunes? ¿Es el principio de legalidad el que proporciona la legitimidad a un régimen democrático o debe más bien la legalidad someterse a algún tipo de prueba de legitimidad sustantiva? $»^{5}$.

Offe y Preuss siguen describiendo cómo las soluciones prácticas a este dilema, arbitradas por las modernas democracias liberales no se han ajustado a ninguna de las dos tradiciones, sino que han sido más bien fórmulas híbridas que, en vez de resolver el problema de cómo educar la voluntad empírica del pueblo, lo han puesto entre paréntesis. Analizando dos de los rasgos institucionales claves de las democracias contemporáneas: el sufragio y el estado de bienestar, concluyen que éstos, lejos de servir a la creación de ciudadanos adultos y responsables, profundizando y ampliando la democracia, han creado sociedades alienantes al sofocar las capacidades racionales y cívicas de los individuos. Tanto el sistema representativo como el estado de bienestar han pretendido conseguir el bien común, sin preocuparse de crear, primero, ciudadanos y ciudadanas capaces de trascender sus intereses particulares y egoístas. La alienación política, que se ha manifestado, al menos, en tres dimensiones: temporal (tensión entre elecciones y decisiones), social (separación entre pueblo y políticos) y sustantiva (distancia entre la ciudadanía y su mundo de la vida y los políticos profesionales, que se traduce en una elite de miopes y oportunistas y en una ciudadanía descapacitada y cínica), ha provocado que ni la legislación realizada a través de los órganos representativos, ni la autoridad legal, hayan bastado para alcanzar la justicia (en áreas como las de protección medioambiental, relaciones entre sexos, comportamiento intergeneracional, Tercer Mundo), ya que «las instituciones representativas han sido a menudo más miopes y menos conscientes sobre los demás o sobre la propia realidad que buena parte de su electorado». ${ }^{6}$ Han sido los movi-

5 Ibid., p. 59.

6 Para abundar en las lacras de las instituciones representativas y de la autoridad legal, véase el magnífico artículo de E. Garzón Valdés. «Instituciones suicidas», en el que analiza pormenorizadamente el comportamiento parasitario de la democracia representativa, 
mientos sociales y no los partidos políticos o parlamentos los que han luchado con más coherencia por el bien común en dichas áreas. En este contexto, Offe y Preuss afirman que se equivocan los críticos de la democracia liberal cuando creen que «el remedio evidente para los resultados irrazonables e injustos de la acción gubernamental consiste en la extensión de la co-determinación y de la participación democrática en las categorías de la población admitida a participar (mujeres, adolescentes, inmigrantes, etc.) tanto como en lo referente a las áreas sustantivas de participación (gobierno local, empresas, servicios, universidades, etc.). De hecho, esta consideración ha perdido buena parte de su capacidad de convicción» ${ }^{7}$. En efecto, cuando se trata de proteger derechos y libertades fundamentales de individuos o colectivos marginados, no basta con lograr mayorías numéricas, ya que con frecuencia la opinión mayoritaria es contraria a las verdaderas reformas democráticas (xenofobia, machismo, etc.). Se trata de cambiar primero la mentalidad mayoritaria para culminar dichas reformas con éxito. El fracaso de la solución híbrida socialdemócrata se ha basado, sobre todo, en no haber buscado prioritariamente la existencia de ciudadanos virtuosos capaces de dar verdadero contenido democrático a las leyes políticas y a las normas sociales, capaces de anteponer la libertad disciplinada y austera del ciudadano a la libertad negativa y egoísta del consumidor satisfecho y recluido en su jardín tapiado ${ }^{8}$.

Podríamos decir que el liberalismo moderno, en su doble versión liberal y socialdemócrata, ha fracasado al no haber podido vencer la lógica del individualismo posesivo y del propietarismo. No ha bastado con la proclama universalista de que para ser ciudadano no hay que ser propietario. De hecho, la lógica propietarista ha seguido vaciando de contenido al ejercicio de la ciudadanía democrática. Seguimos prisioneros de un dilema de difícil solución: pretendemos llegar a ser ciuda-

del Parlamento, de los partidos, etc. «La ética, dirá, es indispensable para el control de las instituciones que, libradas a sí mismas, tienden a autodestruirse, si no formalmente, sí substancialmente. Lo grave no es el simple hecho del "suicidio" sino las consecuencias del mismo dado el tipo de instituciones a las que quiero referirme: la democracia y el mercado». Isegoría, N. ${ }^{\circ} 9,1994$, p. 64.

7 Offe y Preuss, Op. cit., p. 67. Obviamente, estos autores son partidarios de radicalizar el principio de participación democrática, tanto cuantitativa como cualitativamente, pero siendo conscientes de que sólo una actitud ética puede posibilitar que los individuos egoístas se transformen en ciudadanos responsables.

${ }^{8}$ No se trata de minusvalorar los logros que ha supuesto el Estado de Bienestar, especialmente en su tarea asistencial, reduciendo los efectos desigualitarios del liberalismo, sino de reconocer sus limitaciones estructurales tanto en lo económico, como en lo cultural y político. Véase T. Montagut. «Republicanismo y Estados de Bienestar», en Claves de Razón Práctica. N. ${ }^{\circ}$ 112. Mayo 2001. pp. 41-47. 
danos virtuosos sin tener que renunciar al individualismo posesivo. Los arreglos institucionales del constitucionalismo estarán condenados al fracaso, mientras no abjuremos del credo de la biblia burguesa, tal como lo formuló Locke. El pretendido consenso legitimador de nuestras relaciones sociopolíticas estará viciado de raíz mientras sigamos argumentando que podemos ser libres e iguales independientemente de la forma en que se distribuya la propiedad de los recursos escasos. Mientras tanto, las preguntas de Offe y Preuss siguen sin encontrar la respuesta adecuada.

\section{La respuesta del republicanismo}

El republicanismo pretende sanar de raíz este fracaso histórico y cree poder hacerlo recuperando y reformulando la tradición republicana. El republicanismo es un nuevo intento de configurar una sociedad democrática, volviendo a las fuentes de la tradición revolucionaria americana, aunque esta vez la interpretación que de las mismas se hace no se basa ya fundamentalmente en el individualismo liberal, convencionalmente asociado a dicha tradición, sino en otras tradiciones cívicas republicanas, como el humanismo cívico, el iluminismo o el puritanismo y el radicalismo inglés 9 .

Algunos de los republicanos más relevantes parten de la creencia de que la genuina inspiración teórica de la tradición político-institucional angloamericana tuvo un carácter claramente antiliberal. Los americanos construyeron un ideal positivo de libertad, vinculándola a la participación política y a la fundación de una comunidad, mientras que los franceses tuvieron una concepción negativa de la libertad, como liberación de la opresión del Antiguo Régimen. Por eso los americanos crearon un gobierno moderado, que reflejaba y potenciaba el pluralismo y las libertades concretas, mientras que los franceses sustituyeron un gobierno absoluto y despótico por otro gobierno absoluto y democrático, centralizador y coactivo, hasta vincular libertad, virtud y terror. Para los americanos, la sociedad sería, según esta interpretación, un todo, cuyas partes deben convivir armónicamente y estar debidamente integradas. Son partes de un todo. El Estado estaría llamado a desempeñar un importante papel, ya que se le concibe comprometido con la excelsa tarea de obtener buenos ciudadanos. Por eso, dispondría de poder coer-

9 Roberto Gargarella. Las teorías de la justicia después de Rawls. Paidós. 1999, pp. 161 ss. H. Arendt es una de las autoras que ha abundado en esta interpretación de la revolución americana. 
citivo para cultivar ciertas virtudes y para postergar otras, para restringir unos derechos y promover otros, etc. Gargarella ilustra la pertinencia de esta interpretación del republicanismo revolucionario americano en la forma en que se restringieron algunos derechos (limitación de la propiedad privada, de los bienes suntuarios y de los libelos infamantes) y se promovieron otros (discusión y deliberación, economía al servicio del Bien Común, sostenimiento de una determinada religión y de una identidad comunitaria) ${ }^{10}$. Nos encontraríamos, paradójicamente, con un imaginario revolucionario no muy lejano al de la interpretación más convencional, que yo comparto, según la cual el modelo americano sería claramente liberal y partidario de la mínima intervención del Estado, al contrario del francés, partidario de una legalidad y de un Estado fuertes que cargan con la tarea de convertir a los individuos en ciudadanos.

\section{El republicanismo, ¿una «tercera vía» entre el liberalismo y el comunitarismo?}

No es fácil dar una definición precisa de lo que es el republicanismo. Como dice A. De Francisco: «Debo avisar, sin embargo, de que el republicanismo, pasado y presente, no es monolítico, ni unívoco, sino plural y variado. Hay, en efecto, un republicanismo conservador y tradicionalista y otro progresista y posilustrado. Hay un republicanismo liberal y otro antiliberal; hay un republicanismo éticamente comunitarista y otro individualista; lo hay protosocialista y lo hay indiferente a las formas de propiedad; hay un republicanismo instrumental y otro profundo; hay también un republicanismo más plebeyo y otro más patricio; y hay, incluso ahora, un republicanismo pagano y otras formas claramente contaminadas de cristianismo.» ${ }^{11}$

Un autor tan relevante como N. Bobbio, en una entrevista que le hacía recientemente Mauricio Viroli, autor de un libro de explícita confesión republicanista ${ }^{12}$, decía lo siguiente: «En mi formación como estudioso de la política, no me he encontrado ni con el republicanismo, ni con la república»... A decir verdad se ha publicado recientemente una recopilación de escritos míos —alrededor de setecientas páginas-, Teoria generale della política, y en el índice -minuciosísimo- no

\footnotetext{
10 Ibid.

11 Andrés de Francisco. Op. cit., p. 42.

12 M. Viroli. Repubblicanesimo. Turín. Laterza. 1999.
} 
aparece la voz «republicanismo», ni tampoco, y me duele decírtelo, «república»...Desde mi punto de vista, la república es un estado ideal que no existe en ninguna parte. Se trata de un ideal retórico. Por eso me resulta difícil comprender el sentido que tu le das a república y republicanos». ${ }^{13}$ Parece como si estuviéramos oyendo el eco de J. Adams, el antagonista de Jefferson y partidario de una «república monárquica», quien en 1807 decía: «Nunca entendía qué era una república, ni ningún hombre lo hizo o lo hará nunca; una república puede significar cualquier cosa, todo o nada» ${ }^{14}$.

No faltan otros autores que cuestionan la naturaleza específica del republicanismo, ya que no sería más que una forma de liberalismo, para unos, o una expresión de comunitarismo, para otros. H. Béjar dice que «el republicanismo actual tiene un carácter híbrido. Mezcla los elementos del clásico, centrado en la comunidad política, con los componentes de una comunidad sobre todo moral. De ahí el encabalgamiento del republicanismo contemporáneo con el comunitarismo». ${ }^{15}$ De hecho, liberales y comunitaristas han encontrado en el republicanismo un arsenal de argumentos para cuestionar la posición de su contrario y para reforzar la propia.

Finalmente, hay un buen número de autores, que se definen como republicanistas y que, a pesar de lo inasible e impreciso del concepto, y más allá de los parentescos teóricos con el liberalismo y el comunitarismo, creen que el republicanismo tiene un contenido propio y se esfuerzan por describir unos rasgos que definen como su «mínimo común denominador». Creo que expresa bien esta fe la conclusión a la que llega, Salvador Giner, que es entre nosotros uno de sus promotores. «El liberalismo fragmenta. El comunitarismo aísla. El republicanismo, en cambio, relaciona.» ${ }^{16}$.

${ }^{13}$ N. Bobbio-Mauricio Viroli. «Diálogo sobre la República». Revista de Libros. N. ${ }^{\circ} 48$, Diciembre 2000. p. 40.

14 J. Adams, en M. B. Levy (comp.), Political Thought in America: An anthology, Chicago, Dorsey Press, 1988, p. 93. Citado por H. Béjar. Op. citada. P. 66.

15 H. Béjar. Ibid. p. 147.

16 S. Giner. «Las razones del republicanismo» en Claves de Razón Práctica. N. 81. p. 12; véase, asimismo, Giner, S. «Cultura republicana y política del porvenir», en S. Giner (coord.) La cultura de la democracia: el futuro. Ariel. Barcelona. 2000. pp. 137-174. No es fácil dar una lista de autores republicanistas. Nombres como Pocock, Skinner, Pettit, Wolin, Sullivan, Putnam, Bellah, etc, nos indican la dificultad de delimitar la lista... Pettit da una lista en la nota 2 de la página 25 de su obra Republicanismo. Una teoría sobre la libertad y el gobierno. Paidós. Barcelona. 1999. Textos importantes, posteriores al de Pettit, son los de A. Lintott. The Constitution of the Roman Republic. Clarendon Press. Oxford. 1999; Q. Skinner. Liberty before Liberalism. Cambridge University Press. 1998; M. Viroli. La sonrisa de Maquiavelo. Tusquets. Barcelona. 2000. 
En mi opinión, por lo que a los republicanistas confesos se refiere, nos encontramos ante una construcción teórica de un republicanismo que, como decía Bobbio, nunca ha existido como lo presentan sus promotores. Es el fruto de una mirada selectiva a la rica tradición del pensamiento político occidental, en la que no faltan autores y experiencias de las que aprender e intuiciones con las que abordar la búsqueda de solución a los problemas que nos aquejan. Pero creo que el republicanismo de los clásicos y, sobre todo, las experiencias históricas que han querido plasmarlo, adolecen, en la mayoría de los casos, de un carácter antidemocrático, aristocratizante y vinculado a una concepción propietarista de la libertad, que sólo una reconstrucción utópica del mismo puede pensar en él como el referente válido para construir sociedades democráticas en el sentido cabal del término.

El mismo Giner lo confiesa así, cuando dice: «Aunque mi argumentación se inscriba en la tradición democrática republicana, rompe en más de un sentido con algunos de sus supuestos. Es menos tradicionalista. Tengo la impresión de que el actual reavivamiento del interés por el republicanismo sufre de un excesivo historicismo. Bien está que la teoría democrática republicana de hoy se esfuerce por adquirir más dignidad teórica con la codificación del hábeas clásico heredado. Lo está menos, sin embargo, que soslaye las cuestiones con las que tiene que habérselas hoy toda la filosofía pública. Nuestro interés permanente por Maquiavelo como primer teórico moderno del republicanismo mal puede justificar una nostalgia por Maquiavelo... Lo que me interesa aquí, exclusivamente, es aprovechar algunos aspectos del potencial teórico del republicanismo para discernir de qué modo puede ayudarnos tanto a mantener como a hacer florecer la democracia en las arduas condiciones del presente» ${ }^{17}$. Es la misma posición que manifiesta $\mathrm{Ph}$. Pettit, cuando de forma reiterada va recordando a lo largo del texto que él trata de «interpretar según las perspectivas progresivamente cambiantes e iluminadoras de una sociedad viva» los ideales y preocupaciones de los republicanos clásicos, «a veces, ofreciendo incluso reformulaciones harto heterodoxas de sus contenidos» ${ }^{18}$.

Es preciso, por tanto, mantener una actitud crítica ante el republicanismo que no nos impida aprovechar su virtualidad para nuestro queha-

17 S. Giner. Ibid. P. 3.

$18 \mathrm{Ph}$. Pettit. Op. cit. p. 226. Es un mérito reconocido el actualizar la tradición republicana, pero una de las acusaciones que se hará a Pettit es que muestra un afán excesivo por lograr demasiados aliados para el republicanismo. Véase. J. Ferejohn. «Pettit's Republic», en The Monist. Vol. 84. 2001, pp. 77-97. El número está dedicado monográficamente al tema del republicanismo. 
cer democrático, pero que tampoco nos lleve a hipotecar ante él la originalidad y virtualidad de otras formas diferentes de pensar y de actuar, que puedan ser dinamizadoras de dicho quehacer democrático. Creo que para esto conviene no olvidar que si el republicanismo se ha convertido, como dice Gargarella, en «lugar de reposo» de los críticos del liberalismo y del comunitarismo, se debe a que como la virtud aristotélica, en la que el republicanismo encontraría uno de sus pilares, se sitúa «en el medio», como el tertium capaz de subsanar los defectos y de aplacar los excesos de los extremos. Ph. Pettit subraya esta virtualidad del republicanismo, capaz de responder suficientemente a las inquietudes razonables de unos y otros. Personalmente, confieso que las terceras vías me provocan una reacción de recelo que espero no me impida acercarme a él con la objetividad imprescindibe. Por otro lado, no me parece mal que en esta «edad de los extremos» de que habla Hobsbawn, se hagan esfuerzos por ofrecer perspectivas originales razonadamente integradoras.

\section{El modelo de democracia republicana}

Hay una coincidencia entre los diferentes autores que se declararan partidarios del republicanismo en resumir lo específico del mismo en algunas notas características:

\section{El ideal de libertad como no-dominación}

El núcleo axiológico más importante del republicanismo vendría plasmado por el ideal de libertad, entendido como ausencia de dominación y como autogobierno. El «prefiero la peligrosa libertad a la tranquila servidumbre» de Rousseau resumiría bien este talante anti-tiránico que rechaza todo lo que suponga relaciones de dominación y de servidumbre sociales y que, en el imaginario del republicanismo, viene encarnado por la monarquía, expresión de una sociedad organizada desde la arbitrariedad que suponen la jerarquía y el vasallaje. El autogobierno se entiende, en primer lugar, como la libertad política de un estado libre, que, a su vez, posibilitará la comunidad de ciudadanos libres. Por eso, el autogobierno se constituye desde y con instituciones libres, que, a su vez, son escuelas de libertad en las que la ciudadanía aprende a deliberar y a compartir valores y creencias.

Frente a las dos concepciones convencionales de la libertad: la concepción negativa de la libertad como no-interferencia y la concepción positiva de la libertad como autocontrol, los republicanistas presentan una 
tercera concepción alternativa de las anteriores que es la «libertad como no-dominación», que exige que nadie sea capaz de interferir arbitrariamente en la vida de otra persona. Frente al liberalismo que entiende que cualquier interferencia es mala, porque niega la autonomía y el autocontrol, el republicanismo cree que esto sólo ocurre con la interferencia que es arbitraria, pero no con la interferencia que garantiza la libertad, como ocurre con la interferencia legítima del derecho y del Estado. Como dice Pettit, la libertad como mera no-interferencia puede ser compatible con una relación de dominación, cuando el que tiene la capacidad de dominar no interfiere arbitrariamente en la vida de los demás por razones subjetivas, pero podrá hacerlo si cambia de parecer. Para el republicanismo, la libertad sólo se garantiza cuando se incapacita a la autoridad para la interferencia arbitraria. Sólo entonces se posibilita ser libre sin incertidumbre, sin tener que practicar la deferencia estratégica frente al poderoso o sin subordinarse a los demás. La dependencia genera temor ante el poder arbitrario y el temor produce una falta de ánimo y de coraje que se traduce en servilismo, lo que es incompatible con ser un ciudadano que se atreve a mirar a todo el mundo, incluida la autoridad, de frente ${ }^{19}$.

La libertad de toda dependencia arbitraria se consigue sometiendo a todo el mundo al derecho, garantía de que nadie va a actuar arbitrariamente. Como dice Viroli, comentando las obras de Skinner y Pettit, «quien se remita a la tradición republicana debe elegir las políticas que atenúan la dominación, y no aquellas que tratan de atenuar los deberes civiles en nombre del deseo de quedar libres de impedimentos... los republicanos deben situar la ausencia de dominación por encima de la ausencia de interferencia, puesto que esta elección se halla más en consonancia con el ideal de la república entendida como una comunidad de individuos en la que nadie está obligado a servir y donde a ninguno se le consiente dominar.» ${ }^{20}$

Lo dicho no significa que los republicanos no aprecien la libertad negativa del liberalismo, como ausencia de interferencia, sino que el valor de esta última está condicionado a que se haga desde la inaccesibilidad de la autoridad a la interferencia arbitraria. De ahí, la importancia decisiva que para el republicanismo tiene el derecho como condi-

19 Para abundar en la clarificación de los conceptos de «interferencia» y «dominación» y en cómo ambos pueden ser instrumentalizados para disminuir la libertad, obstruyendo la habilidad de las personas para planificar su propia vida, véase S. Hall. «Freedom, Interference and Domination», en Political Studies. Vol. 49. N. 2 June 2001.

20 M. Viroli. Revista de Libros. N. ${ }^{\circ}$ 52. Abril 2001. p. 8. La obra de Q. Skinner ha sido pionera en la recuperación del Republicanismo. Véase Los fundamentos del pensamiento político moderno. Fondo de Cultura Económica. 2 vol. México, 1985 y 1986. Para nuestro tema, es de especial interés el tomo I dedicado al Renacimiento; véase pp. 61 ss.; 132 ss.; 183 ss. La obra de Pocock sirve de inspiración y contrasta a la de Skinner. 
ción de posibilidad de la libertad. La libertad como no-dominación tiene necesariamente una dimensión política, intrínsecamente institucional, que es la que nos protege de la interferencia arbitraria. No puede dejarse, dice Pettit, en manos de los individuos para que éstos la persigan a su aire, según sus fuerzas, de forma descentralizada, ya que nos encontraríamos con los problemas del estado de naturaleza hobbesiano, sino que hay que confiar en la previsión constitucional; «todo indica que lo mejor es perseguirla para cada uno mediante la acción política de todos: perseguirla por vía estatal» ${ }^{21}$.

Pero los republicanos son conscientes de que también el Estado, sus autoridades y sus leyes, pueden ser arbitrariamente manipulados y convertirse en una amenaza de dominación: la «del imperium del Estado». Para eliminar dicha amenaza, ser democráticamente controlado en el estado republicano debe satisfacer plausiblemente algunas condiciones constitucionalistas y debe responder de sus decisiones. Entre estas condiciones constitucionalistas, Pettit menciona tres genéricas: el imperio de la ley y no de los hombres (principio de legalidad y procedimentalismo), la dispersión del poder (separación de poderes, bicameralismo y federalismo) y «la garantía de que las leyes imperantes no sean fácil y excesivamente mudadizas bajo la presión de la mayoría». Ahora bien, como el imperio de la ley no debe identificarse necesariamente con el «imperio del código» ni comprometernos con un procedimentalismo extremo, se deberán contemplar diversas formas de discrecionalidad, siempre que ésta se ejerza bajo las restricciones que contribuyen a contener la arbitrariedad. Una de estas restricciones básicas consiste en que, en el marco de una república deliberativa, una democracia más de disputa o de disenso que de consenso, la gente pueda discutir las decisiones públicas, sobre todo, si entran en conflicto con sus intereses o formas de pensar. «Lo que importa no es el origen histórico de las decisiones en alguna forma de consentimiento, sino el que respondan modal o contrafácticamente a la posibilidad de disputa»22. Para que esto pueda darse es preciso que en la discusión prime la razón sobre el interés («república de razones», que debe alejarse del modelo mercantilista de afirmar las preferencias), que todo el mundo tenga voz (y que las voces tengan crédito por ser representativas) y que siempre exista el Foro adecuado para debatir y en el que las quejas y disputas hallen la audiencia adecuada ${ }^{23}$.

21 Ph. Pettit. Op. cit., p. 353.

22 Ph. Pettit. Op. cit., p. 242. Para este tema, véase el capítulo VI de la obra.

${ }^{23}$ Sobre la necesaria vinculación que existe entre deliberación (buena), toma de decisión (justa) y participación (decisiva para la economía de la virtud y para un proyecto repu- 
Pero los republicanos son conscientes de que para que este proyecto sea factible y estas recomendaciones no se queden, como dice Pettit, en deseos piadosos, hay que pensar en cómo ayudar a personas humanas de naturaleza imperfecta y corruptible, especialmente a las autoridades que gozan del privilegio del poder, a no caer en ejercicio arbitrario del mismo. Un pesimismo respecto a la corruptibilidad de los seres humanos en posiciones de poder, combinado con un relativo optimismo respecto de la naturaleza humana en cuanto tal, lleva a republicanos, como Pettit, «a diseñar instituciones que funcionen bien tanto para agentes que no están realmente corruptos, como para, una segunda trinchera defensiva, agentes que lo están». Una adecuada combinación de cribas (selección adecuada de los funcionarios públicos y de sus opciones) y de sanciones (castigos y recompensas no alienantes), permitirá lograr evitar los efectos perversos de un control basado en la estrategia pesimista de la desviación (ocultación de la virtud, etiquetación, dependencia de las sanciones, provocación, corporatismo, selección adversa) y lograr motivar positivamente a los funcionarios. Disciplinar a los funcionarios y comunicarles a la vez una imagen positiva de su virtud es el arte de usar bien lo que Pettit llama «la mano intangible»: lo que supone la consideración y el respeto de los demás como estímulo para la propia virtud (frente a la «mano invisible» del liberalismo economicista o la «mano de hierro» de la burocracia liberticida).

La extraordinaria importancia que para los republicanos tiene el pensar en el diseño institucional de ámbitos tan cotidianos y concretos como los descritos nace de la convicción de que los grandes ideales como «libertad» y «república» descansan «en ordenamientos que, en sustancia, son pedestres y hasta aburridos». Por eso, Pettit, hace propia la acusación que se hacia a los fabianos de ser «socialistas de agua y gas», para «argüir a favor de una especie de republicanismo de agua y gas» ${ }^{24}$.

Obviamente, para los republicanos, con ser tan importante todo lo dicho sobre el diseño institucional orientado a asentar el constitucionalismo, el edificio republicano carecería de base sólida si no estuviera sostenido, a su vez, por una red de normas cívicas que sean aceptadas de forma generalizada por la población y que sirvan como refrendo crítico del ejercicio legítimo del poder por parte de las autoridades. Un clima de civilidad que sancione, aplaudiendo y reprobando las conduc-

blicano coherente), véase Ovejero, F. «Democracia liberal y democracias republicanas. Para una crítica del elitismo democrático», en Claves de Razón Práctica. ‥ ${ }^{\circ} 111$. Abril 2001. pp 18-30.

24 Ph. Pettit. Ibid., p. 310. 
tas ciudadanas, según se ajusten o no al código de civilidad republicana, permitirá que funcione con eficacia la estrategia de la «mano intangible». El Estado republicano desconfía tanto de un orden espontáneo («mano invisible») como de un orden impuesto («mano de hierro») y favorece un control que supone tanto la interiorización ciudadana de los valores de la civilidad republicana, como el sentido de pertenencia e identificación con los grupos que defienden y hacen suyos dichos valores. Es importante resaltar esto último, ya que, como sigue diciendo Pettit, esta identificación es algo natural que servirá para hacer menos costoso de lo que puede parecer el cumplir con el ideal de civilidad republicana. «De manera que no es necesario un milagro de autonegación para que se den en una comunidad manifestaciones de una civilidad ampliamente difundida; esa civilidad tiene que limitarse a ser testigo de la naturaleza irrepresiblemente social de nuestra especie» ${ }^{25}$. Interiorizar la civilidad republicana e identificarse con los grupos que la hacen suya genera necesariamente un clima de confianza, que tiene la doble virtualidad de que, por un lado, en las relaciones sociopolíticas no se pondrá en peligro el ideal de libertad como no-dominación, y, por otro, de que se podrán aplicar medidas de control sobre las autoridades, sin tener que aplicar la estrategia de la desviación antes señalada y dejada de lado por los republicanos.

\section{¿República de la virtud?}

Está claro que el ideal de libertad como no-dominación sólo es posible con la virtud cívica, que es la piedra angular del proyecto político republicano. Sin ciudadanos y ciudadanas virtuosos, que sean capaces de participar con competencia y responsabilidad en la sociedad y que lo hagan de forma altruista y solidaria, no es posible que subsista el orden republicano. Los clásicos han incidido de forma constante en este aspecto.

Pero el realismo que nace de la evidencia sociológica de la calidad moral del ser humano medio obliga a reconocer, como dice Giner, lo que los clásicos, libres de complejos demóticos, planteaban: que, dado que la distribución social de la virtud es esencialmente asimétrica (dada la existencia de servidumbres propias de la desigualdad social y, sobre todo, dada la heterogeneidad de los seres humanos), «toda politeya compleja presencia la formación de una clase cívica en su seno... En condiciones de relativa estabilidad, la clase cívica abarca a una colecti-

25 Ibid., p. 136. 
vidad transclasista forzosamente minoritaria y, en sí, también heterogénea ${ }^{26}$. El republicanismo clásico prima una visión organicista de la sociedad, concibiendo a ésta como una comunidad ética articulada, en la que, aunque los ciudadanos no sean elites en el sentido convencional, no son asimilables a las masas, que para el republicanismo son siempre germen de despotismo y de la nueva forma de tiranía moderna: la tiranía de las mayorías. Los ciudadanos son alumnos aventajados que han sido capaces de autoseleccionarse destacando en el arte de la virtud cívica. Obviamente, ante esta forma de «elitismo» el republicanismo actual debe responder a la cuestión de si la mayoría de los ciudadanos en «circunstancias normales» son capaces de culminar con éxito este aprendizaje ético.

Los republicanos de nuestros días subrayan que el ideal de ciudadanía no exige seres humanos con madera de santos políticos o incorruptibles heroicos a lo Robespierre, que suelen ir asociados a los terrores virtuosos de tan infausta memoria, sino que está al alcance de la mayor parte de la ciudadanía, siempre que se sepa aplicar la pedagogía adecuada. Giner dice que la noción de clase cívica, igualitaria y libre, es diametralmente opuesta a la facción jacobina de los ciudadanos supuestamente virtuosos, a la «clase universal» ungida con destinos providenciales emancipatorios, o a la clase de un partido de iluminados, que en el pasado han sido fuente de tantas patologías sociales y de tanto sufrimiento humano. M. Viroli, dice al respecto: «Cierto, para mí, la virtud civil no consiste en la voluntad de inmolación por la patria. Se trata de una virtud civil para hombres y mujeres que desean vivir con dignidad y que, puesto que saben que no cabe vida digna en una comunidad corrupta, hacen lo que pueden, cuando pueden, para servir a la libertad común: desarrollan su profesión a conciencia, sin tratar de obtener ventajas ilegítimas ni aprovecharse de la necesidad o debilidad de los otros; viven la vida familiar sobre una base de respeto recíproco, de modo que su casa se parece más a una pequeña república que a una monarquía o a una congregación de extraños reunidos por el interés o la televisión; asumen sus deberes cívicos sin asomo de docilidad; son capaces de movilizarse para impedir que se apruebe una ley injusta o para forzar que quien gobierna afronte los problemas ateniéndose al interés común; participan en asociaciones varias (profesionales, deportivas, culturales, políticas y religiosas); prestan atención a las vicisitudes de la política nacional e internacional; quieren comprender, negándose al seguidismo o al adoctrinamiento; desean, en fin, conocer y discutir

26 S. Giner. Op. cit., p. 8. 
la historia de la república y reflexionar sobre la memoria histórica». Tras afirmar que la heterogeneidad de motivos que llevan hombres y mujeres al compromiso sirve para el reforzamiento mutuo de los mismos, concluye diciendo que «no es una virtud civil imposible. Cualquiera de nosotros podría citar el nombre de muchas personas que responden a esta descripción del ciudadano dotado del sentido de la responsablidad civil, y que sólo han hecho el bien a la comunidad y a sí mismos» 27 .

Es claro que los republicanos modernos, que son conscientes de que este ideal de ciudadanía es incompatible con algunos rasgos típicos del republicanismo clásico, como el propietarismo, la hostilidad hacia la disidencia y heterogeneidad sociales, la exclusión de los incapaces de independencia material y moral, como los negros y las mujeres, la supeditación del individuo a la comunidad, etc., lo que hacen es potenciar la dimensión relacional y societaria del republicanismo, exculpándolo tanto del individualismo posesivo subyacente al propietarismo liberal, como del colectivismo y comunitarismo totalitarios propios de los proyectos tribales. Los individuos en el republicanismo se relacionan desde el altruismo y la fraternidad, fuentes de la verdadera libertad, la positiva. Su individualismo no es como el liberal, jusnaturalista, racionalista y contractualista. No necesita la hipótesis del estado de naturaleza para legitimar el origen de la sociedad y el papel de las instituciones, siempre al servicio de los individuos y de sus derechos, sino que parten de que el ser humano es, como decía Aristóteles, un animal político dotado de lenguaje moral. La sociedad no carece de legitimidad de origen, aunque esté permanentemente necesitada de legitimación racional y moral, algo que realizan sus miembros cuando se comportan con la racionalidad y moralidad derivadas de su naturaleza final que es la ciudadanía. Lo individual y lo colectivo participan de una misma naturaleza humana, política y moral.

El igualitarismo formal de la democracia liberal necesita llenarse de contenido con la virtud de la justicia, que sólo puede realizarse con una concepción republicana de la propiedad, es decir, responsable y consciente de que su telos, como en Aristóteles, exige autolimitación y solidaridad, que se traduzcan en una verdadera versión del Estado social. No parece compatible con el ideal de una comunidad de iguales, en la que toda la gente disfrute con igual intensidad de la no-dominación, el que haya diferencias estructurales que hacen a unos más vulnerables, más pobres y más desgraciados, sin que los demás se sientan

27 M, Viroli. Op. cit., p. 41. 
responsables de la situación. Sin caer en los excesos de la retórica colectivista, pero en coherencia con la lógica republicana que los revolucionarios franceses tuvieron presente cuando hablaban de libertad, igualdad y fraternidad, «querer la libertad republicana es querer la igualdad republicana; realizar la libertad republicana, realizar la comunidad republicana» ${ }^{28}$.

El patriotismo republicano se distancia, asimismo, del nacionalismo excluyente, ya que defiende un marco común para toda la ciudadanía, fomentando, como dice Giner, «la universal deferencia ante las diferencias» ${ }^{29}$. Aunque sigue incomodando la advertencia rousseauniana de que el republicanismo es incompatible con un universalismo que relativiza la lealtad exclusiva a la patria. No parece que sea tan fácil eliminar del republicanismo y de su voluntad general el riesgo excluyente de los comunitarismos.

\section{Republicanismo y sociedades capitalistas}

Sin querer cuestionar la coherencia lógica del discurso republicano, me surge, una y otra vez, la pregunta de si el republicanismo, a la hora de proponer su ideal ético y político, se hace de verdad cargo de la realidad de nuestras sociedades modernas, pluralistas y organizadas conforme al paradigma del capitalismo liberal, especialmente, en esta etapa que, autores, como Dussel y otros, han calificado con acierto como la «edad de la globalización y de la exclusión». Aunque son varias las cuestiones que, en mi opinión, hacen problemática la viabilidad del proyecto republicano, como la asunción del pluralismo, de la tolerancia y de la neutralidad, exigencias de la sociedad democrática, me puedo dejar de referirme a una cuestión que ya mencioné al comienzo y que me parece determinante para nuestro tema. Me refiero al propietarismo.

Si en la ciudad estado-griega el republicanismo prima lo público sobre lo privado, el bien común sobre el interés particular, y la propiedad privada es algo subordinado e instrumental, al servicio del ejercicio de la ciudadanía, no ocurre los mismo en nuestras sociedades. Mientras que en el republicanismo clásico, la política es un ideal de vida en común, una paideia que modela la vida individual y la pone al servicio desinteresado de la patria (educación y ejército), en nuestras sociedades ocurre lo contrario. La política es un instancia útil e incluso

28 P. Pettit, Op. cit., p. 169.

29 S. Giner, Op. cit., p. 10. 
necesaria, pero instrumental al servicio de la «sociedad civil» y del individualismo propietario. El comercio sustituye a la milicia y el intercambio entre iguales se convierte en el motor de las relaciones sociales. La ciudadanía sirve para disfrutar de los derechos y libertades de forma pacífica y segura, pero no exige renunciar a las propias pasiones e intereses. La red de instituciones que vertebran la socialidad sirven, a la vez, para corregir las pasiones y para educar en la virtud ciudadana.

Si las cosas son así, parece que estamos buscando la cuadratura del círculo. Creo que, en sociedades colonizadas por el espíritu del capitalismo, el republicanismo está condenado a ser una fórmula más, cargada en exceso de discurso normativo, mientras no plantee abiertamente la necesidad de «reabrir la cuestión del capitalismo». Propiedad privada y comunidad ética, como virtud republicana y comercio, son difícilmente compatibles, más allá de la débil vinculación que supone la socialidad moderna. El corazón de la república sigue atravesado por una pasión radicalmente antirrepublicana como es la del individualismo propietario ${ }^{30}$.

\section{Republicanismo y cristianismo}

El republicanismo de los clásicos, como hemos visto, ha compartido un ideal de libertad y de autogobierno, de humanismo cívico, que en buena medida se ha ido configurando como la negación de una situación de tiranía, de monarquía absolutista y despótica, de sacralización irracional de estructuras sociales estamentales y jerárquicas... El hecho de que el cristianismo, al menos en las versiones más oficiales de las confesiones católica, protestante y ortodoxa, se haya vinculado históricamente a la causa de la monarquía del Antiguo Régimen ha sido motivo suficiente para convertirse en el blanco de sus críticas y hasta de su negación por el republicanismo. Se ha llegado a convertir en un lugar común entre los historiadores republicanos (Pocock, Skinner) el afirmar que el republicanismo se ha desarrollado al margen e incluso en contra de la tradición cristiana.

El citado Pettit confiesa en el Prefacio de su obra que el ideal republicano de libertad como no-dominación, cautivó inmediatamente su imaginación, «tal vez porque daba sentido a mi experiencia cuando, en vías de ser sacerdote, pasé varios años en organizaciones que más tarde

30 Para abundar en el tema, véase artículo de D. Velasco. «La Tercera Vía y las legitimaciones de un nuevo socialismo», en Iglesia Viva. N. ${ }^{\circ}$ 207. 2001. 
aprendí a describir, en los términos de E. Goffman, como instituciones totales. Aunque estas escuelas y seminarios ofrecían grandes oportunidades de estudio y camaradería, desde luego no nos enseñaron a mirar a las autoridades de frente, confiados en saber cuál era nuestra posición y ajenos al temor de estar sujetos a juicio caprichoso. Al contrario: se nos comunicaba un sentido de vulnerabilidad y exposición sistemáticas al arbitrio de la autoridad, haciendo a veces incluso virtud de esa práctica. Yo tuve que poner cota a la subordinación inherente a esa educación, y la noción de libertad como no-dominación ofrecía una vía satisfactoria para explicar qué había de malo en esas prácticas. Nuestra formación había tratado de cultivar la ilibertad; estaba pensada para producir estudiantes pasivos, sin criterio, inseguros de su posición.» ${ }^{31}$

Una gran parte de la historia del catolicismo y una experiencia biográfica como la de Pettit, seguramente compartida por una gran mayoría de fieles católicos, siguen siendo argumentos incontestables para afirmar que la Iglesia católica es uno de esos modelos de «sociedad total» en la que no se educa para la mayoría de edad o para el ejercicio de la libertad como no-dominación. Para mí, la cuestión ahora, es si, más allá de los argumentos aducidos por republicanos como Pettit, que en gran medida comparto ${ }^{32}$, se puede también sostener que es el mismo cristianismo el que queda cuestionado desde este ideal de libertad republicano y que la génesis y desarrollo del republicanismo nada ha tenido que ver con la tradición cristiana.

En mi opinión, es obvio que la vinculación de la Iglesia con la tradición monárquica, símbolo de los valores antirrepublicanos, es fruto de una contingencia histórica que, por muy larga que haya sido, no se puede legitimar desde una genuina concepción cristiana de la libertad. Al contrario, el republicanismo debería ser para la Iglesia un argumento que le llevara a recuperar la verdadera inspiración evangélica que, sin duda alguna, está mejor encarnada por el ideal republicano de libertad como no-dominación que por la sórdida experiencia de la servidumbre voluntaria. La Iglesia debería reapropiarse la gran lección republicana de que la lógica inmanente a la «economía de la salvación»

31 Pettit, Ph. Op. cit., p. 12.

32 Véase D. Velasco. Derechos humanos y Doctrina Social de la Iglesia: del anatema al diálogo. Universidad de Deusto. 2000. Creo que es pertinente recordar aquí la distinción adleriana entre «la idea de esclavitud», que la Iglesia rechaza, y la «institución social de la esclavitud», que la Iglesia practica, tanto en el sentido institucional, jurídico-político de la misma (como ideología de dominación) como en su forma espiritual (dogmatismo doctrinal y dominación de las conciencias). Véase T. De la Rocca. «La transformation du christianisme dans la société occidentale, selon Max Adler», en Social Compass. N. ${ }^{\circ} 40.1993$, pp. 83-90. 
le exige poner los medios institucionales necesarios para evitar el ejercicio arbitrario de la autoridad y del poder en la Iglesia, tanto ad intra como ad extra. Y digo «reapropiarse», porque creo que hay una larga tradición cristiana, que se remonta al cristianismo primitivo y que ha perdurado a lo largo de toda la historia occidental, que ha tenido un carácter republicano y que buena parte de los autores que se citan como testigos del republicanismo anticristiano no habrían sido republicanos a no ser por su inspiración cristiana. ${ }^{33}$ Pero, antes de abundar en el rigor analítico de esta convicción, veamos cuáles son los argumentos que algunos autores republicanos han aducido contra el cristianismo.

\section{Las críticas del republicanismo clásico al cristianismo}

Para una mayoría de los clásicos del republicanismo, el cristianismo ha sido responsable de que la dimensión política de la vida humana se haya convertido en algo accidental y secundario, hasta llegar a vaciarse de contenido ético y de virtualidad sociogenética y humanizadora. La prioridad de la dimensión espiritual del ser humano individual, identificada, a su vez, con un mundo religioso y trascendente, en el que el creyente se juega su salvación eterna, se afirma a costa de lo que supone la afirmación del mundo de lo temporal. En todo caso, los verdaderos lazos comunitarios con los que el creyente debe desarrollar su vocación se tejen en el ámbito de una comunidad eclesial y de un «cuerpo místico» que, por su propia lógica, se van a convertir en antagonistas del mundo político secular y que van a exigir de sus miembros una fidelidad y una obediencia que ningún otro imperativo de pertenencia política o social podrá poner legítimamente en cuestión. La cuestión de la doble pertenencia y de la doble fidelidad de los cristianos tendrá una de sus expresiones más genuinas en la relativización de la política y del poder temporal en función del fin más importante de todo ser humano que es la salvación.

Según algunos autores, como es el caso de H. Arendt, los estoicos, primero (y las escuelas menores en general), y los cristianos, más tarde, silenciaron la dimensión política del ser humano, entendida como el ejercicio de una actividad creadora, dialógica y pública, tal como lo concibe Aristóteles. En efecto, con la caída de la ciudad-estado griega desaparece el ciudadano como sujeto político y se convierte en súbdito de una organización imperial y despótica del poder. Los estoicos em-

33 Véase A. Black. «Christianity and Republicanism: From St. Cyprian to Rousseau». American Political Science Review. Vol. 91, N. ${ }^{\circ}$ 3. Sept. 1997, pp. 647-656. 
prenden la tarea de reconstruir un nuevo concepto de ciudadanía, ahora vaciado de todo contenido político concreto y fundamentalmente referido a una ciudad cosmopolita, identificada con el mundo planificado desde la Providencia divina. La operación ideológica estoica que, como dice Wolin ${ }^{34}$, es, a la vez, una desnaturalización de la política y una politización de la naturaleza, sólo es posible porque el nuevo ciudadano estoico centra todo su esfuerzo en construirse, como dice G. Sabine, lentamente un alma. Lo que le importa, sobre todo, es la interioridad del ser humano, que vinculado religiosamente a un destino universal y divino debe saber cumplir sabiamente con su vocación, sin dar demasiada importancia a las contingencias históricas y políticas de este mundo terrenal. La importancia del status sociopolítico del individuo es algo accidental. Marco Aurelio y Epicteto podrán compartir su vocación «estoica» sin que lo impida su respectiva condición de emperador y de esclavo.

El cristianismo habría seguido esta forma de estoicismo resignado, que, depreciando el valor de este mundo pasajero, centra todo su interés en alcanzar la salvación definitiva. Esta se juega, fundamentalmente, en el ámbito de la interioridad de cada ser humano, en la forma en que se es fiel a una vocación que sólo cada uno conoce y que se descubre tras una laboriosa tarea de introspección contemplativa. Lejos queda el ruido del ágora y, más lejos aún, el ideal heroico asociado al riesgo de afrontar la vida pública con coraje y creatividad. La vida pública pierde su virtualidad realizadora de ciudadanos éticos, libres e iguales, y se convierte en el inevitable marco en que los creyentes deben llevar a cabo su vocación. Los demás, ya no son los «otros» con quienes formamos una misma comunidad «agonal», sino los miembros de un «cuerpo místico» al que pertenecemos por lazos misteriosos y sacramentales, cuando son creyentes fieles a la disciplina eclesial, o, simplemente, los súbditos de un poder que todos debemos obedecer porque así lo quiere Dios. Si este poder se pone al servicio de la causa de los creyentes, quienes lo ejerzan y quienes lo sufran gozarán de un plus de legitimidad y de legitimación de los que, por supuesto, carecen quienes no la sirven.

La sociedad que construyen tanto los estoicos como los cristianos dejaría, pues, sin peso específico a «lo político» y lo convertiría en algo instrumental y accidental respecto a lo religioso. La dimensión espiritual e interior de la libertad, que es la que cuenta, es perfectamente

34 Wolin, S.S. Politica y perspectiva. Continuidad y cambio en el pensamiento político occidental. Amorrortu. Buenos Aires. 1973, pp. 89-93. 
compatible con una situación de dependencia e incluso de servidumbre sociopolíticas. En escenario así dibujado, estaríamos imposibilitados para pensar el valor de la libertad como no-dominación.

A lo largo de la historia occidental, esta forma de entender la relación entre cristianismo y política ha sido reafirmada por buena parte de los clásicos del pensamiento político moderno, especialmente en contextos en los que el cristianismo se ha asociado a formas premodernas o reaccionarias de legitimación del poder político. En el caso de los autores de la tradición republicana, como Maquiavelo, Rousseau, Montesquieu, la razón aducida en su crítica del cristianismo será casi la misma que he descrito, ya que nace tanto de su pasión por recuperar la herencia clásica de una ciudad-estado idealizada, como de su visión negativa del papel del cristianismo en la historia de Occidente.

Para Maquiavelo, por ejemplo, el ideal republicano renacentista, del que participa y que reformula, se traduce en una permanente lucha contra la necesidad y la fortuna, que se alimenta de la virtud, del coraje, de la astucia, de la disciplina, de la versatilidad agonal del actor, obligado sin cesar a dislocar su personalidad dependiendo de las circunstancias siempre cambiantes del escenario político. Para la actividad política, el cristianismo es un mal consejero, ya que promueve actitudes de pasividad, resignación, ausencia de coraje cívico y de patriotismo, rechazo a la milicia armada y a la religión civil, y carece de las otras virtudes consideradas imprescindibles cuando se trata de defender la libertad y el autogobierno ${ }^{35}$. No se trata, pues, de que Maquiavelo no sea consciente de la enorme importancia que tiene la religión en su época, de su influencia en el comportamiento de sus conciudadanos, de su capacidad de crear cohesión social y de otras

35 «Y así puede verse, analizando atentamente la historia romana, qué útil resultó la religión para mandar los ejércitos, confortar a la plebe, mantener en su estado a los hombres buenos y avergonzar a los malos... Teniendo en cuenta todo esto, concluyo que la religión introducida por Numa se cuenta entre las primeras causas de la felicidad de aquella ciudad, porque ella produjo buenas costumbres, las buenas costumbres engendraron buena fortuna, y de la buena fortuna nació el feliz éxito de sus empresas». Discursos sobre la primera década de Tito Livio. I, 2, Alianza Universidad. Madrid. 1984, pp. 64-66. Refiriéndose al cristianismo dice: «Nuestra religión ha glorificado más a los hombres contemplativos que a los activos. A esto se añade que ha puesto el mayor bien en la humildad, la abyección y el desprecio de las cosas humanas, mientras que la otra lo ponía en la grandeza de ánimo, en la fortaleza corporal y en todas las cosas adecuadas para hacer fuertes a los hombres. Y cuando nuestra religión te pide que tengas fortaleza, quiere decir que seas capaz de soportar, no de hacer, un acto de fuerza. Este modo de vivir parece que ha debilitado al mundo, convirtiéndolo en presa de los hombres malvados, los cuales lo pueden manejar con plena seguridad, viendo que la totalidad de los hombres, con tal de ir al paraíso, prefieren soportar sus opresiones que vengarse de ellas». Ibid. II, 2. p. 188. 
virtualidades sociopolíticas. Pero no cree que sea el cristianismo que conoce el que pueda cumplir adecuadamente esta función. La verdad es que, como señalan los intérpretes autorizados de Maquiavelo (Leo Strauss, Q. Skinner, C. Lefort, J.G. A. Pocock), tampoco la religión y la virtud clásicas, tal como las podían entender los sabios de la época, sirven a Maquiavelo para lograr los fines patrióticos que persigue. Su ruptura con el humanismo cívico lo sería también con el humanismo clásico. Maquiavelo está pensando en la virtud estrictamente política y en función de ella hay que entender su propuesta de «religión civil».

La religión civil de Rousseau, que aparece como el auxilio imprescindible que subsana las deficiencias congénitas del bello pero frágil edificio de la racionalidad contractualista rousseauniana, es también polémicamente anticristiana. El cristianismo se alejó, desde un comienzo, del ideal pagano de una ciudad-estado en la que la religión era fuente de entusiasmo, de entrega activa, de patriotismo y de comunidad de conciudadanos. La ciudadanía cristiana, por el contrario, tiene un carácter universal, ya que se basa en la convicción de que la fraternidad universal es el auténtico origen y destino de todos los seres humanos. La patria de los cristianos poco tiene que ver con el patriotismo republicano. Las virtudes vinculadas a este último poco valor pueden tener para quien tiene sus ojos puestos en la salvación eterna en cuyo logro debe invertir todos sus talentos ${ }^{36}$. La pasividad respecto al compromiso sociopolítico del cristianismo sólo se romperá para traer la ruina a la república. En efecto, el carácter congénitamente intolerante de la dogmática cristiana se traduce en el peor de los vicios, como es la intolerancia civil o el fanatismo. El remedio está, pues, en una religión civil deísta y política, a la vez, que discipline, motive e incluso entusiasme con la causa republicana ${ }^{37}$.

Pero Rousseau, como más adelante veremos, difícilmente habría podido escribir su contrato social sin sentirse heredero de una concep-

36 «Pero, al no tener esta religión ninguna relación particular con el cuerpo político, deja a las leyes la sola fuerza que ellas sacan de sí mismas sin añadirles ninguna otra, y por fuerza queda sin efecto uno de los grandes vínculos de la sociedad particular. Más aun, lejos de destinar los corazones de los ciudadanos al Estado, los despega de él como de todas las cosas de la tierra: no conozco nada más contrario al espíritu social... Los verdaderos cristianos están hechos para ser esclavos; lo saben y no se conmueven apenas por ello; esta breve vida tiene poco valor a sus ojos». J. J. Rousseau. Del Contrato Social. Alianza Editorial. Madrid. 1980, pp 136-139. En este último capítulo del Contrato social, Rousseau reitera su rechazo del fanatismo al que considera fruto natural de las religiones dogmáticas como el cristianismo, situándose explícitamente en la estela de Hobbes.

37 Véase J. J. Rousseau, op. cit., p. 140. 
ción ética de la política, que tiene además un claro talante cristiano y «sacramental» que sólo podría explicarse desde una tradición cristiana secularizada.

El caso de Montesquieu es, una vez más, el de un ilustrado, iniciado desde muy niño en los clásicos griegos, profundamente anticlerical, que profesa un deísmo racionalista y que ve en el cristianismo una fuente de intolerancia y de fanatismo que se debe controlar políticamente e instrumentalizar al servicio de la buena marcha de la sociedad. De hecho, en la historia, el cristianismo, y especialmente el catolicismo, ${ }^{38}$ lejos de servir para cuestionar la depravación de la sociedad francesa bajo el despotismo, lo legitima aún más. Aplica a la religión su teoría sociológica de que debe comprenderse en relación con el clima, el tiempo, la historia, el estado social y demás variables que constituyen el secreto de su naturaleza. Bien comprendida y bien utilizada, la religión puede servir a la causa de la libertad y convertirse en un dique contra el absolutismo. Incluso la misma Iglesia, una vez que se limiten su riqueza y su autoridad y se le impida ser intolerante, puede jugar un buen papel en la creación del orden moral y social. Montesquieu, como una gran parte de los autores de la época y como la mayoría de los teóricos de la sociología posteriores veía en la religión una buena fábrica de cemento social y en el ateísmo una fuente de anomía social ${ }^{39}$.

\section{Por un cristianismo republicano}

Pero no todos los autores republicanos han mantenido esta posición de rechazo frente al cristianismo. Allí donde el cristianismo ha sido un factor clave para la construcción del proyecto republicano, la valoración del mismo ha sido, obviamente, muy distinta. Así ha ocurrido en la tradición anglosajona vinculada al puritanismo y radicalismo inglés del siglo XVII, así como a buena parte de la revolución americana ${ }^{40}$. Fi-

38 Refiriéndose a la escisión religiosa provocada por la reforma, dice: «La religión católica conviene más a una Monarquía, y la protestante a una República... Esto se debe a que los pueblos del Norte tienen y tendrán siempre un espíritu de independencia y de libertad que no tienen los pueblos del Sur, y a que una religión que no tiene cabeza visible conviene más a la independencia debida al clima que la que la tiene». Montesquieu. El espíritu de las Leyes. Libro XXIV, cp 5. Tecnos. Madrid. 1972. p. 347. Véanse los capítulos XXIV y XXV dedicados a la relación de las leyes con la religión. Ibid. pp. 343, ss. 3.

39 Véase M. Régaldo, Montesquieu et la religión. Académie Montesquieu, Bordeaux, 1998. Según este autor, Montesquieu heredó de su familia el odio a los jesuitas y el anticlericalismo.

${ }^{40}$ Uno de los primeros textos programáticos de la revolución, como es la Declaración de derechos del Buen Pueblo de Virginia (12/VII/1776), dice así: «Que ningún pueblo 
guras tan importantes como la de A. de Tocqueville son un referente emblemático de todo lo positivo que la religión cristiana aportó a la construcción de la democracia americana y a la democracia, en general, ya que, como él mismo nos recuerda, «en América vio más que América». Son numerosísimos los textos que abundan en el papel decisivo de la religión cristiana en la construcción de la democracia norteamericana. «La mayor parte de la América Inglesa ha sido poblada por hombres que, despues de haberse sustraído a la autoridad del papa, no se habían sometido a ninguna supremacía religiosa. Llevaban, pues, al Nuevo mundo un cristianismo que yo no podía pintar mejor que llamándolo democrático y republicano. Esto favoreció singularmente el establecimiento de la república y de la democracia en los negocios. Desde el principio, la política y la religión se encontraron de acuerdo, y después no dejaron de estarlo» ${ }^{41}$.

Tocqueville, lo mismo que los otros clásicos del pensamiento político ya citados, no está tanto interesado en la religión desde la perspectiva dogmática, cuanto desde la sociológica, y, desde esta última, valora su virtualidad para la defensa de la libertad y de la democracia, que en algunos casos se puede pervertir ${ }^{42}$.

Tocqueville fue muy crítico respecto de un cristianismo evasor, vinculado al despotismo y a la corrupción, del que la historia está pla-

puede tener una forma de gobierno libre, ni los beneficios de la libertad, sin la firme adhesión a la justicia, la moderación, la templanza, la frugalidad y la virtud y sin retorno constante a los principios fundamentales... y que es deber recíproco de todos el practicar la paciencia, el amor y la caridad cristiana para con el prójimo».

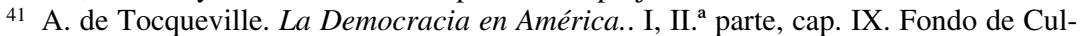
tura Económica. México-Buenos Aires. 1963, p. 287.

42 Cito un texto de la Introducción de La Democracia en América en el que se describe lo que decimos. «Se encuentran aún entre nosotros cristianos llenos de celo, cuya alma religiosa quiere alimentarse de las verdades de la otra vida. Son los que lucharán sin duda a favor de la libertad humana, fuente de toda grandeza moral. El Cristianismo que reconoce a todos los hombres iguales ante Dios, no se opondrá a ver a todos los hombres iguales ante la ley. Pero, por el concurso de extraños acontecimientos, la religión se muestra momentáneamente comprometida en medio de poderes que la democracia derriba, y le sucede a menudo que rechaza la igualdad que tanto ama, y maldice la libertad como si se tratara de un adversario, mientras que, si se la sabe llevar de la mano, podrá llegar a santificar sus esfuerzos. Al lado de esos hombres religiosos, descubro otros cuyas miradas están dirigidas hacia la tierra más bien que hacia el cielo; partidarios de la libertad, no solamente porque ven en ella el origen de las más nobles virtudes, sino sobre todo porque la consideran como la fuente de los mayores bienes, desean sinceramente asegurar su imperio y hacer disfrutar a los hombres de sus beneficios. Comprendo que ésos van a apresurarse a llamar a la religión en su ayuda, porque deben saber que no se puede establecer el imperio de la libertad sin el de las costumbres, ni consolidar las costumbres sin las creencias; pero han visto la religión en las filas de los adversarios, y eso ha bastado para ello; unos la atacan y otros no se atreven a defenderla». A. de Tocqueville. Op. cit. Introducción, pp. 37-38. 
gada de ejemplos. Valga como muestra de esta crítica este texto sacado del Prefacio de El Antiguo Régimen y la Revolución. «Se encontrarán incluso buenos cristianos, porque la patria de éstos no es de este mundo y la gloria de su religión es producirlos en medio de la mayor corrupción de costumbres y bajo los peores gobiernos; el imperio romano en su extrema decadencia estaba lleno de ellos ${ }^{43}$. Pero, siempre, la religión no sólo es un rasgo connatural al ser humano, sino un fuerza con enorme poder de integración y de cohesión social. Mientras que el ateísmo es una fuente de materialismo craso, especialmente peligroso, ya que deriva hacia un individualismo destructivo, la religión es fuente de altruismo y de solidaridad con los demás. Como su coetáneo Stuart Mill, preferirá que el individuo crea en la reencarnación, aunque sea en un cerdo, que el que no crea en nada.

Algunos republicanos actuales subrayan, dentro de esta tradición puritana de la que se sienten herederos, la dimensión bíblica, como uno de los pilares básicos del republicanismo. Parece claro que el referente bíblico de la Alianza, del que surge un nuevo pueblo con seres humanos dotados de un corazón nuevo, es el ejemplo inmediato en el que se inspira el pacto fundacional que da origen a la conversión liberadora y a la nueva sociedad. Desde el proyecto utópico de los hombres de la Quinta Monarquía, a las experiencias americanas del «nuevo Israel»o «Nueva Jerusalén», hay una constante en los movimientos sociales americanos que sería incomprensible sin el horizonte bíblico.

Pero creo que la fuente de inspiración cristiana del republicanismo no se debería circunscribir a esta tradición puritana y bíblica del radicalismo inglés y de la revolución liberal americana, sino que habría que saberla encontrar en los orígenes del cristianismo primitivo y seguir su rastro a través de la historia europea, medieval, moderna y contemporánea. En las próximas páginas intentaré mostrarlo siquiera de forma telegráfica.

\section{¿Un cristianismo y una Iglesia republicanos?}

Creo que hay datos suficientes para poder afirmar convincentemente que la comunidad cristiana primitiva tenía más carácter republicano que monárquico. ${ }^{44} \mathrm{Si}$ por «república» entendemos, como dice

\footnotetext{
43 Tocqueville, A. Op. cit. p. 22.

${ }^{44}$ El uso del concepto republicano es analógico, ya que la Iglesia, como comunidad de creyentes no debería confundirse con ningún régimen político concreto, pero su necesaria institucionalización no permite pensar que la cuestión de la forma de organizar la relación
} 
A. Black, «un orden institucional en el que los gobernantes son elegidos y están sujetos a la ley, las decisiones importantes se toman en grupo y el pueblo es partícipe reconocido de la política, y, además, hay una ética política que obliga a los ciudadanos a preocuparse del bien común y les reconoce el derecho de ser tratados con respeto y equidad por las autoridades públicas ${ }^{45}$, creo que en la ekklesia primitiva todos los creyentes, gozando de un mismo status moral ante Dios, formaban una comunidad universal de bautizados, que no sólo tenía un carácter cósmico y escatológico sino, también, una dimensión institucional y jurídica que daba visibilidad pública a una nueva forma de entender las relaciones humanas y sociopolíticas. H. Küng, refiriéndose a lo que fue el protocristianismo, según el paradigma judeocristiano, dice así: «A la Iglesia del paradigma judeocristiano se le podría aplicar en el mejor sentido el adjetivo democrática (en todo caso, no aristocrática o monárquica): una comunidad en libertad, igualdad y fraternidad. Porque esta Iglesia no era: - una institución de dominación, incluso gran inquisición, sino una comunidad de libres; - una Iglesia de clases, razas, castas o cargos, sino una comunidad de hermanos y hermanas ${ }^{46}$. Y lo que dice del paradigma judeocristiano, lo afirma también del paradigma ecuménico-helenista. No hay duda: si ya a la Iglesia del paradigma judeocristiano se le puede calificar de democrática en el mejor sentido del término, una comunidad en libertad, igualdad y hermandad, tanto más puede aplicarse el adjetivo a las comunidades paulinas. En ningún otro lugar se muestra con claridad tan impresionante como en la frase que Pablo escribe a su comunidad de Galacia: Porque todos, al bautizaros vinculándoos al Mesías, os revestisteis del Mesías. Ya no hay más judío ni griego, esclavo ni libre, varón y hembra, pues vosotros hacéis todos uno, mediante el Mesías Jesús ${ }^{47}$.

Más que la actitud de la comunidad eclesial frente al orden político, que es un tema debatido, como lo muestran los numerosos estudios de sociología del cristianismo primitivo ${ }^{48}$, nos interesa subrayar su forma

eclesial entre salvación, verdad, cohesión y poder, sea intrascendente, ya que no todas las formas de gobierno gozan de la misma legitimidad.

45 A. Black. Op. cit., p. 647.

46 H. Küng. El cristianismo. Esencia e historia. Ed. Trotta. Madrid. 1997, p. 95.

${ }^{47}$ H. Küng. Ibid., p. 136. La cita de Gálatas: Ga. 3, 27-29.

48 Véase, por ejemplo, R. A. Horsley (ed.) Paul and Empire: Religión and Power in Roman Imperial Society. Harrisburg. Pensilvania. Trinnity Press International. 1997, sobre todo, la sección cuarta, en la que escriben autores como P. Donfired, E. Schüssler-Fiorenza y el mismo R. Horsley, en la que presentan una visión paulina de la sociedad de corte igualitarista, en radical oposición a la política imperial; véase, también, J. Churruca. «Actitud del cristianismo ante el imperio romano», en Poder político y derecho en la Roma clásica. Ed. Complutense. Madrid. 1996, pp. 139-189. 
de entender la propia vida comunitaria, su nuevo ideal de comunidad que, a pesar de que su finalidad última fuera trascendente, convocaba a los fieles a una original forma de participación mucho más intensa que la participación política clásica. El corpus Christi, figura utilizada en los clásicos y que hará suya la Iglesia, quiere reflejar la imagen plástica de ser un «cuerpo vivo», dotado de una vida tan rica e intensa y de unas cualidades místicas y espirituales que hace que sus miembros se sientan religados por unos lazos afectivos y por una fuerza emocional absolutamente desconocidos para el mundo clásico.

Hay un texto que recogen los tres sinópticos que, también, puede servir de pórtico para una relectura del cristianismo desde la clave del republicanismo. «Sabéis que los que son tenidos por jefes de los pueblos los gobiernan tiránicamente, y que los poderosos los oprimen con injusticias. No tiene que ser así entre vosotros. El que quiera ser el mayor, que sea vuestro servidor; y el que quiera ser el primero, que sea esclavo de todos. Pues tampoco el hijo del Hombre ha venido a ser servido sino a servir y a dar su vida en rescate por todos» (Mc. 10, 41-45). La libertad que nace del Espíritu, de la verdad, de la condición de hijos de Dios, no es compatible con ninguna servidumbre ni dominación. «De la servidumbre al servicio» ha sido el lema que no pocos exegetas han utilizado para expresar el proyecto liberador que inspira toda la historia de la salvación, tal como se concibe en la experiencia cristiana. Aunque ya, desde finales del siglo I, haya una preocupación por resaltar la virtualidad nómica del cristianismo para la sociedad secular y para el orden público, se de una recepción del lenguaje jurídico romano para expresarlo y, finalmente, se acepten estructuras diocesanas, que reflejaban la de las provincias romanas, sin embargo, el espíritu que anima la configuración eclesial tiene un carácter propio y original que se expresa en clave republicana o, dicho con mayor propiedad, sinodal. El concilio de Jerusalén, tal como se describe el los Hechos de los Apóstoles, podría servir de paradigma en la praxis institucionalizadora y constituyente de la Iglesia. Recordemos que, en un principio, la pluralidad de corrientes de tradición, no eran tanto diferentes grupos en el sentido de entidades con una vida propia y sociológicamente distinta, cuanto diversas tendencias, definidas por su posición concreta ante la circuncisión (judaizantes o no), más que por su carácter etnocultural (judeo-cristianos y cristianos de la gentilidad, o paulinos y petrinos). ${ }^{49}$ La toma de decisiones y la recepción eclesial de las mismas tendrá un carácter consensuado.

49 Véase V. Fusco. Les premières communautés chrétiennes. Ed. Du Cerf. Paris. 2001. 
Los cristianos se creen el nuevo pueblo elegido por Dios y la Ekklesia adquiere el doble significado de ser un ideal trascendente de comunidad escatológica, la de los salvados y, a la vez, el de ser la asamblea de los cristianos en un lugar concreto. Un reto permanente para la iglesia primitiva será el permanecer unida, ordenada, y siempre contando con el consenso, sin el que no se comprenden ni la libertad ni la obediencia bien entendidas. La forma en que se aborda la sucesión apostólica, que acabará vertebrando la institución de la Iglesia católica, es muestra de cómo un proceso de constitucionalización se construye en referencia a algo que viene revelado, dado de lo alto y, a la vez, a un logro institucional que se alcanza a través de la negociación y el consenso. Discusiones, sínodos provinciales o nacionales, concilios, son el ejemplo más patente de lo que decimos. La unión de la Iglesia refleja la legitimidad que nace de la búsqueda común de la verdad y del consenso. ${ }^{50}$ Buscar la implicación del mayor número posible de participantes en la generación del consenso a la hora de tomar las decisiones se convirtió en una forma de actuar típica del sinodalismo, como lo será más tarde del republicanismo. Hasta mediados del siglo II, en que se configura la estructura de un episcopado monárquico, el modelo eclesial más común es el colegial y sinodal.

Desde el concilio ecuménico de Nicea, este proceder de la Iglesia primitiva se convertiría en un precedente, inédito hasta entonces, que inspirará el pensamiento y la praxis política occidental, hasta nuestros días ${ }^{51}$. Más allá de la necesaria institucionalización de la Iglesia que, como sabemos, se hizo liquidando las corrientes milenaristas y heréticas que, ante el inminente Apocalipsis, no querían perder ni tiempo ni radicalidad evangélicos en las tareas organizativas, a las que consideraban de naturaleza perversa, fue la forma que tuvo la Iglesia de resolver

${ }^{50}$ La figura de San Cipriano, obispo de Cartago, subrayó de forma reiterada, en unos momentos de gran tensión intraeclesial el carácter consensuado y colegiado de la autoridad episcopal y se convirtió en un importante referente para el constitucionalismo medieval. Su sentencia «nada sin vuestro consejo y sin el consenso del pueblo», aplicado a su tarea episcopal, es reflejo de un quehacer episcopal vinculado a formas estructurales de consenso. Véase H.J. Sieben. "Consensus, unanimitas und maior pars auf Konzilien, von der Alten Kirche bis zum Ersten Vatikanum», en Von Apostelnkonzil bis zum Ersten Vatikanum. Paderborn. 1996. pp. 510-511; asimismo, Angelo de Bernardino. «Caminos de koinonía en los primeros siglos cristianos». Concilium. N..$^{\circ}$ 291, junio 2001, pp. 46-64.

51 No se trata de magnificar en exceso el carácter autogestionario del sinodalismo, ya que, como es sabido, los emperadores ejercieron un importante papel de tutelaje en la convocatoria y el control de los concilios, pero sí de subrayar adecuadamente el significado de dicho fenómeno. Esto es especialmente significativo en el momento actual de la Iglesia, cuando el Vaticano aborta con su centralismo uniformizante la virtualidad de los sínodos, como ha ocurrido con el sínodo africano. 
sus conflictos, tanto los relacionados con las disputas a propósito de los recursos escasos: cargos, honores, dineros, como, sobre todo, los conflictos primarios, relacionados con la constitución de la Iglesia misma, la que reveló una conducta política de la Iglesia de singular significado e importancia. Las técnicas de transacción y de negociación mencionadas son la demostración de una elasticidad e inventiva eclesiales tan ricas que sin ellas sería incomprensible una parte importante de la tradición política occidental, incluida la republicana.

Me parece, pues, que no se debe seguir manteniendo la imagen infundada de que la historia del cristianismo, desde Constantino a Lutero, ha sido la de una monarquía papal. Creo que, más allá de la imagen de Bonifacio VIII y del agustinismo político triunfantes o de la aprobación del «dogma» de la infalibilidad papal en el Vaticano I, lo que la historia del pensamiento político evidencia es la permanencia de una denuncia constante de la pretensión papal de legislar y determinar la doctrina sin contar con el consenso conciliar. En efecto, la relevancia de lo consensual en la organización y en el quehacer eclesiales ha sido enorme a lo largo de toda la Edad Media. Parece evidente que la Iglesia fue por delante de las experiencias comunales y que éstas estuvieron inspiradas y legitimadas por elementos religiosos que garantizaban la fidelidad y la cohesión. Sin desconocer el papel que, sin duda, tuvieron en la creación del republicanismo medieval y renacentista los ejemplos del mundo clásico y del mundo germano ${ }^{52}$, el modelo eclesial parece obvio que ha tenido una singular importancia, dada la simbiosis que en no pocos casos se daba entre lo cristiano y lo secular. El referente de un movimiento religioso de enorme trascendencia, en el que hay que inscribir por su singular relevancia a las órdenes mendicantes, y, más en concreto, a la orden de los dominicos, debe tenerse en cuenta para encontrar un ámbito paradigmático de constitucionalismo. No hay que olvidar, por otro lado, que no pocos de los humanistas retóricos de las repúblicas italianas, por ejemplo, no se mostraron partidarios de los aspectos más democráticos del republicanismo. El ejemplo de Savonarola, expresión de un idealismo cristiano, no debería olvidarse cuando se reflexiona sobre el republicanismo de la época. Se sobredimensiona injustamente el alcance de la figura de Maquiavelo, cuando se quiere subrayar el carácter anticristiano de dicho republicanismo.

El Conciliarismo es el ejemplo más evidente de que en la historia del cristianismo occidental ha existido una gran afinidad entre republi-

52 Véase el capítulo que G. Sabine dedica al tema en «El pueblo y la ley» de su obra Historia de la teoría política, que apenas se suele tener en cuenta. Fondo de Cultura Económica. México-Madrid-Buenos Aires. 1945, pp. 154-171. 
canismo y cristianismo. ${ }^{53} \mathrm{El}$ intento de reformar la Iglesia imponiendo al papa la voluntad conciliar suponía reafirmar la permanente creencia en la autoridad de los concilios, reafirmar la cultura constitucionalista de las comunas y parlamentos medievales y actualizar la cultura cívica respublicana. Si hay algo esencial en la constitución de la Iglesia es esta capacidad del concilio de poder destituir al papa. El hecho de que el papado saliera vencedor de la crisis del conciliarismo, no significa que éste desapareciera de la historia. Su relevante papel en el calvinismo posterior y en todo lo que dicho calvinismo generó, como ya hemos mencionado al hablar del puritanismo, son una muestra clara de lo que decimos. Creo que se puede decir, con razón, que si el fracaso del conciliarismo en el interior de la Iglesia católica sirvió para ir desterrando progresivamente de la misma el proyecto republicano de ekklesia, su éxito en la historia nacida de la Reforma protestante, especialmente la calvinista, y su influencia en el pensamiento secularizado de la Ilustración deben ser necesariamente tenidos en cuenta a la hora de explicar las relaciones entre republicanismo y cristianismo.

Pero, incluso, al referirnos a la Iglesia católica, creo que hay una experiencia frustrada que podía haber resucitado en la Iglesia su mejor tradición de republicanismo. Me refiero a la de la Iglesia constitucionalista francesa que vio en la revolución no sólo un peligro para la Iglesia, sino, sobre todo, una oportunidad para una nueva y más evangélica configuración de la misma ${ }^{54}$. Si la mentalidad hegemónica en la Iglesia no hubiera sido la del pensamiento reaccionario, las cosas se habrían resuelto de otra manera y el pensamiento que inspiró la obra revolucionaria habría podido ser entendido de forma diametralmente opuesta a como se hizo. Así, por ejemplo, Rousseau, en vez de ser condenado como uno de los corifeos diabólicos de la conspiración del mal, podría haberse comprendido como un divulgador de la versión secularizada de lo que debería ser una comunidad cristiana. Rousseau es, en mi opinión, el autor que, obsesionado por la degradación moral de la sociedad (tan bien descrita en sus discursos) busca una fórmula que la regenere de raíz y cree haberla encontrado en su Contrato social, que es un re-

53 Véase la obra del mismo A. Black. Political Thought in Europe, 1250-1450. Cambridge University Press. Cambridge. 1992.

54 Véase D. Velasco, «Los antecedentes histórico-ideológicos de la Declaración Universal de los Derechos del Hombre de 1948» en La Declaración Universal de los derechos humanos en su cincuenta aniversario. Universidad de Deusto. 1999, pp. 275 ss., en donde describo la situación y explico el porqué del desenlace contrarrevolucionario. Recojo solamente la opinión que Touchard pone en boca de Monseñor Affre. «...que la causa del sacerdote es la causa del pueblo y que fue Jesucristo el primero que dio al mundo la causa republicana: libertad, igualdad y solidaridad». Véase H. Küng, Op. cit., p. 736. 
flejo de la eclesiología cristiana. En efecto, en el momento sacramental del contrato, el individuo pasa del estado de naturaleza al civil y experimenta una conversión moral e intelectual que le convierte en miembro de la nueva comunidad política, del nuevo cuerpo místico cuya voluntad general será la garantía infalible de salvación. Es como si estuviéramos refiriéndonos al bautismo cristiano, que, además de rescatar al ser humano del reino del pecado, le introduce en la comunidad salvífica de la Iglesia, de cuyo cuerpo formará siempre parte. La verdadera libertad del creyente estará vinculada en adelante a la comunión con la comunidad eclesial, como la libertad del ciudadano estará intrínsecamente vinculada a la obediencia al contrato y a sus leyes. Las características que tiene la voluntad general de Rousseau son de neto origen eclesiológico, como se muestra en los numerosos documentos conciliares que usan términos análogos para calificar a la autoridad revestida de voluntad general. Los lazos de amistad y fraternidad que vinculan al creyente con la Iglesia se subsumen en el concepto de ciudadanía ${ }^{55}$. El hecho de que, como ya hemos visto anteriormente, Rousseau no explicite su república en clave cristiana, sino deísta, no quita peso al argumento de que su republicanismo no sólo no es incompatible con el cristianismo, sino que es de clara inspiración cristiana.

Como concluye Black en su citado artículo, del análisis histórico ideológico se pueden sacar dos conclusiones claras. La primera que no existe un conexión necesaria entre cristianismo y monarquía. El que se hayan aducido argumentos teológicos de diverso tipo para argumentar a favor de dicha conexión no deja de ser algo contingente y arbitrario, porque, y es la segunda conclusión, existen argumentos teóricos y prácticos para vincular cristianismo y republicanismo, como hemos podido comprobar. Es obvio que ninguna de estas conexiones posibles, monárquica o republicana, agota la posibilidad que tiene el cristianismo de inculturarse en ideas y formas políticas del más diverso alcance. En estos tiempos, en los que el reto del multiculturalismo nos obliga a resituar de forma modesta la historia de las ideas y de las formas políticas occidentales, e incluso al cristianismo en su configuración occidentalista, es importante no simplificar las cuestiones y no cerrarse nunca a la mutua fecundación que nace de dos ilustraciones: la de la razón y la de la fe. Republicanismo y cristianismo pueden fecundarse mutuamente, especialmente en estos tiempos en que necesitamos construir una democracia global: de ciudadanos libres e iguales y con institucio-

55 Son seis veces las que he contabilizado en el Contrato Social de Rousseau en que se habla de esta conversión del individuo en ciudadano y de lo que la misma supone. Véase Rousseau. Op. cit., pp. 226 y ss. 
nes responsables que garanticen unas relaciones humanas basadas en la no-dominación. Tanto el republicanismo como el cristianismo van a ser necesarios para posibilitar esta tarea.

\section{Cristianismo y virtud republicana}

Si el cristianismo ha creado desde sus orígenes una estructura institucional legitimada en el consenso, ha sido, sin duda alguna, porque la comprensión de la libertad como no-dominación ha inspirado lo más genuino del quehacer cristiano. Ya hemos citado el texto de los sinópticos en donde se afirma explícitamente lo que decimos. Falta, ahora, saber si esta propuesta evangélica, que vincula el ejercicio de la autoridad y de la libertad a la actitud de servicio, posibilita o no el ejercicio de la virtud republicana.

Recordemos que la virtud cívica, que posibilita un ejercicio competente y responsable de la ciudadanía republicana, no es viable en un contexto de masificación, por lo que exige una cierta aristocracia espiritual inmunizada tanto frente al individualismo posesivo como frente al colectivismo totalitario. De hecho, en el republicanismo clásico, este ideal virtuoso estaba hipotecado a rasgos de claro talante elitista y excluyente. Pero, como planteábamos al comienzo de estas páginas, el republicanismo teórico de los modernos tiene todavía por delante el reto hasta ahora irresuelto de hacer plausible para la ciudadanía, universalmente contemplada, la conversión moral de que hablaba Rousseau: trascender el egoísmo y el particularismo y buscar libre y responsablemente el bien común. En algunos de los clásicos más importantes, como Rousseau o Tocqueville, esta conversión sólo era posible gracias al auxilio de la religión, aunque ésta se denomine «civil».

Creo que este papel regenerador de la religión que ha proporcionado la dosis de altruismo universal demandado por el republicanismo, lo ha cumplido y lo puede seguir cumpliendo el cristianismo con éxito. Más allá de la visión tenebrista de los republicanos críticos del cristianismo, hay una amplia tradición cristiana que ha mostrado su extraordinaria virtualidad liberadora. Me limito a recordar que las diferentes teologías de la liberación, que en el siglo $\mathrm{XX}^{56}$ han iluminado el horizonte de una humanidad más libre e igualitaria, han bebido en los filones más vivos de la tradición cristiana y han permitido dinamizar con fuerza las luchas de innumerables personas y comunidades en contra de la dominación y de la injusticia. Creo que no se ajusta a la realidad la identificación del cristia-

56 Véase R. Gibellini. La teología del siglo XX. Sal Terrae. Santander. 1998. 
nismo con un estoicismo resignado o con un cinismo satisfecho, aunque, como ya he reconocido antes, dicha identificación siga dándose en una buena parte de quienes se confiesan cristianos. La misma Iglesia católica tiene pendiente su asignatura «republicana», para ser fiel a sus raíces.

Una de las tradiciones más genuinas del cristianismo es la que a lo largo de toda la historia de Occidente ha seguido manteniendo el principio de que Dios ha querido que todos los bienes estén al servicio de todos los seres humanos. Es verdad que la forma concreta en que la Iglesia ha legitimado la propiedad privada y la desigualdad ha sido un blasfemo mentís de la voluntad salvífica, liberadora y universal del Dios cristiano. Pero, en lo más coherente de su doctrina y de su praxis, no ha faltado nunca la denuncia del propietarismo injusto. Desde la patrística a la doctrina social de la Iglesia, hay testimonios claros de lo que decimos. Me limito a recordar encíclicas actuales, como la Populorum Progressio, de Pablo VI, o la Sollicitudo Rei Socialis, de Juan Pablo II, que, en mi opinión, son dos de las críticas más consecuentes al proceso de globalización economicista, el peor de los enemigos de un verdadero proyecto democrático y republicano ${ }^{57}$.

Finalmente, si, como afirma H. Béjar, la levadura del republicanismo fermenta en el mundo del asociacionismo y de las redes ciudadanas, del voluntariado y de los nuevos movimientos sociales, creo que hay que constatar como un significativo dato sociológico, que una buena parte de los miembros que conforman esta nueva realidad social lo hace desde una inspiración cristiana. Es verdad que no es fácil evaluar la calidad de la «virtud republicana» que se supone subyace a dicha realidad y que, en no pocos casos, pueda ser meramente la expresión de una nostalgia de la plusvalía espiritual que el estilo de vida materialista genera en muchos creyentes. Pero, no lo es menos, que para otros muchos el evangelio cristiano es fuente inagotable de compromiso para vivir humanamente, libres de toda dominación e injusticia, y para solidarizarse con quienes las padecen.

Concluyo con la advertencia que J. B. Metz hacía a ilustres representantes de la Ilustración, con motivo del cuarenta aniversario de la publicación de la Dialéctica de la Ilustración de Adorno, afirmando que la cultura de la Ilustración, como cultura de la libertad, de la democracia y de los derechos humanos, si quiere tener futuro, debe abrirse a las aportaciones que puede ofrecerle la memoria de Dios de la tradición bíblico-cristiana, «la cual todavía hoy permite hablar de humanidad y de solidaridad, de opresión y de liberación, y protestar contra una injusticia que clama al cielo» ${ }^{58}$.

57 Véase D. Velasco. Derechos humanos y Doctrina social de la Iglesia: del anatema al diálogo. Universidad de Deusto 2000, pp. 29-42.

58 Citado por R. Gibellini. Op. cit., p. 14. 